Syntax Literate: Jurnal Ilmiah Indonesia p-ISSN: 2541-0849

e-ISSN: 2548-1398

Vol. 7, No. 1, Januari 2022

\title{
PENGATURAN TENGGAT WAKTU PELAKSANAAN PIDANA MATI DALAM HUKUM PIDANA INDONESIA
}

\section{Dimas Pranowo}

Kejaksaan Republik Indonesia, Kejaksaan Negeri Belitung Timur, Indonesia

Email: dimas.pranowo@gmail.com

\begin{abstract}
Abstrak
Dalam praktik penerapan eksekusi pidana mati seringkali para terpidana hukuman mati harus menunggu hingga bertahun tahun sampai pada hari pelaksanaan eksekusi mati. Ketidak jelasan mengenai waktu pelaksanaan pidana mati tersebut menimbulkan ketidak pastian hukum bagi para terpidana. Penelitian ini hendak membahas penerapan pidana mati dan masa tunggu bagi terpidana dalam menjalankan hukuman mati dalam sistem hukum pidana di Indonesia. Penelitian disusun dengan metode yuridis normative dengan menganalisis peraturan perundang undangan terkait hukuman mati. Hasil penelitian menunjukkan Hukum Pidana Indonesia dalam UU Nomor 2/PNPS/1964 tidak mengatur secara pasti tentang waktu pelaksanaan eksekusi bagi terpidana hukuman mati sehingga penelitian ini menyimpulkan perlu adanya pengaturan yang tegas batas tenggat waktu untuk pelaksanaan eksekusi mati.
\end{abstract}

Kata Kunci: masa tunggu; pidana mati; kepastian hukum

\section{Abstract}

Indonesian Criminal Law does not specify the timing of execution for death row convicts. In the practice of the execution of the death penalty, the death penalty convicts often have to wait for years until the day of execution. The lack of clarity regarding the timing of the execution of the death penalty creates legal uncertainty for the convicts. This research intends to discuss the application of the death penalty and the waiting period for convicts in carrying out the death penalty in the criminal law system in Indonesia. Research is structured by normative juridical methods by analyzing laws and regulations related to the death penalty. The results showed that the Indonesian Criminal Law in Law No. 2/PNPS/1964 does not regulate definitively the timing of executions for death row inmates so this study concluded that there needs to be a firm setting of deadlines for the execution of executions.

Keywords: waiting time; dead penalty; law certainty

Received: 2021-12-20; Accepted: 2022-01-05; Published: 2022-01-15

\begin{tabular}{ll}
\hline How to cite: & Pranowo. D (2022) Pengaturan Tenggat Waktu Pelaksanaan Pidana Mati dalam Hukum Pidana Indonesia. Syntax \\
& Literate: Jurnal Ilmiah Indonesia, 7(1). http://dx.doi.org/10.36418/ Syntax-Literate.v7i1.6034 \\
E-ISSN: & 2548-1398 \\
Published by: & Ridwan Institute
\end{tabular}




\section{Pendahuluan}

Hukum pidana secara garis besar dapat dibagi menjadi tiga bagian yaitu hukum pidana materiil, hukum pidana formil,dan juga hukum pelaksanaan pidana (Marbun, 2014). Masing masing dari ketiga jenis pidana ini memiliki fungsi dan perannya yang berbeda beda. Apabila hukum pidana materiil menentukan perbuatan perbuatan apa saja yang dilarang dan diancam dengan sanksi pidana, maka hukum pidana formil adalah isntrumen hukum pidana yang melaksanakan ketentuan dalam pidana formil sekaligus mengatur panduan dalam beracara di dalam persidangan. Berbeda dengan hukum pidana formil, menurut (Lamintang, 2017), hukum eksekusi pidana merupakan instrument hukum pidana yang berfungsi untuk mengatur masalah pidana dan pemidanaan beserta lembaga pidana atau pemidanaan (Lamintang, 2017). Ketiga jenis pidana ini memiliki keterkaitan satu dengan yang lainnya dan ketiadaan salah satu dari pidana tersebut akan berdampak pada tidak dapat dilaksanakannya tujuan pemidanaan.

Berbicara pidana, maka tidak dapat dilepaskan dari ketentuan sanksi pidana. Sanksi pidana diberikan kepada setiap orang yang melanggar ketentuan yang ada di dalam ketentuan pidana materiil (KUHP). Menurut (Sudarto, 2013), pidana pada dasarnya adalah nestapa/ penderitaan yang dikenakan kepada setiap orang yang memenuhi unsur unsur tertentu (Sudarto, 2013). Dalam diskursus ilmu hukum pidana, jenis jenis sanksi tersebut dikenal sebagai stelsel pidana. Stelsel pidana diatur di dalam ketentuan Pasal 10 KUHP yang mengatur bahwa sanksi pidana adalah:

1. Pidana mati

2. Pidana penjara

3. Pidana kurungan

4. Pidana denda

Selain pidana pokok sebagaimana yang diatur di dalam Pasal 10A KUHP, ketentuan Pasal 10 B KUHP juga mengatur tentang pidana tambahan yang masing masing adalah:

1. Pencabutan hak hak tertentu

2. Perampasan barang barang tetentu

3. Pengumuman putusan hakim

Dalam studi kejahatan, korupsi sangatlah luas dan meliputi beberapa tipe. Paling tidak ada sembilan tipe korupsi dalam studi kejahatan menurut (Hiariej \& Uno, 2020). Pertama, political bribery adalah termasuk kekuasaan di bidang legislatif sebagai badan pembentuk undang-undang. Secara politis badan tersebut dikendalikan oleh suatu kepentingan karena dana yang dikeluarkan pada masa pemilihan umum sering berkaitan dengan aktivitas perusahaan tertentu. Para pengusaha berharap anggota yang duduk di parlemen dapat membuat aturan yang menguntungkan mereka. Kedua, political kickbacks, yaitu kegiatan-kegiatan yang berkaitan dengan sistem kontrak pekerjaan borongan antara pejabat pelaksana dan pengusaha yang memberi peluang untuk mendatangkan banyak uang bagi pihakpihak yang bersangkutan. Ketiga, election fraud adalah korupsi yang berkaitan langsung dengan kecurangan pemilihan umum. Keempat, 
corrupt campaign practice adalah praktek kampanye dengan menggunakan fasilitas negara maupun uang negara oleh calon yang sedang memegang kekuasaan negara.

Kelima, discretionery corruption yaitu korupsi yang dilakukan karena ada kebebasan dalam menentukan kebijakan. Keenam, illegal corruption yakni korupsi yang dilakukan dengan mengacaukan bahasa hukum atau interpretasi hukum. Tipe korupsi ini rentan dilakukan oleh aparat penegak hukum, baik itu polisi, jaksa, pengacara, maupun hakim. Ketujuh, ideological corruption ialah perpaduan antara discretionery corruption. dan illegal corruption yang dilakukan untuk tujuan kelompok. Kedelapan, political corruption adalah penyelewengan kekuasaan atau kewenangan yang dipercayakan kepadanya untuk mendapatkan keuntungan pribadi atau kelompok yang berkaitan dengan kekuasaan. Kesembilan, mercenary corruption yaitu menyalahgunakan kekuasaan semata-mata untuk kepentingan pribadi.Masalah pidana dan pemidanaan itu sendiri merupakan obyek kajian dalam bidang hukum pidana yang disebut hukum penitensier (penitensier recht). Oleh karena persoalan hukum pidana yang dikupas atau dibahas dalam hukum penitensier adalah menyangkut masalah pidana dan pemidanaan, maka hukum penitensier itu sendiri dalam arti sempit dapat diartikan sebagai segala peraturan-peraturan positif mengenai sistem pidana (strafstelsel).

Sedangkan dalam arti luas, hukum penitensier dapat diartikan sebagai bagian hukum pidana yang menentukan dan memberi aturan tentang sanksi (sistem sanksi) dalam hukum pidana, yang meliputi baik strafstelsel maupun maatregelstelsel (sistem tindakan) serta kebijaksanaan. Jadi dalam usaha untuk mempertahankan dan menyelenggarakan ketertiban, serta melindunginya dari perkosaan-perkosaan (pelanggaran-pelanggaran) terhadap berbagai kepentingan hukum, maka negara diberi hak dan kekuasaan untuk menjatuhkan pidana serta hak dan kekuasaan untuk. menjatuhkan tindakan dan kebijaksanaan.

Pembaruan hukum pidana dalam rangka penyempurnaan sistem pemidanaan masih terus dilakukan. Dari sekian banyak hal yang akan diperbarui, satu hal penting dalamsistem pemidanaan yang juga krusial disediakan dalam pembaruan hukum pidana Indonesia adalah sistem pemidanaan struktural. Ini merupakan hal yang sebetulnya patut dimasukkan dalam konsep pembaruan hukum pidana. Menurut (Barda Nawawi Arief, 2018) seharusnya tidak hanya berfungsi fragmenter, tapi harus totalitas dan struktural. Selama ini hukum pidana Indonesia yang merupakan turunan langsung dari Weetboek van Straftrecht (WvS) Belanda masih memberlakukan hukum pidana secara individual, padahal model ini sudah mulai dianggap tidak proporsional lagi.

Ternyata dalam logika dan fakta hukum, sering tindak pidana tidak hanya bisa dilakukan individual sehingga pertanggungjawaban pidananya pun tidak bisa individual. Dalam berbagai bentuk tindak pidana (baik WvS maupun konsep baru KUHP) juga diatur tentang adanya "pelaku", "yang menyuruh melakukan", dan "turut serta melakukan" tindak pidana. Logika pertanggungjawaban struktural merupakan kaitan yang boleh jadi menginspirasi atau lalai baik terhadap pengawasan maupun tanggung jawab sehingga terjadinya tindak pidana. Artinya bahwa jelas dalam tindak pidana dan pertanggungjawaban pidana dapat melibatkan pihak lain selain pelaku secara individual. 
Pertanggungjawaban pidana dalam hal ini tidak bisa dilihat hanya dalam pelaksanaan tindak pidana, tetapi uga memperhatikan hubungan-hubungan psikologis dan historis pelaku tindak pidana, yang tetap harus dalam bingkai rasionalitas. (Barda Nawawi Arief, 2016) mengistilahkan sebagai kebijakan integral dalam penanggulangankejahatan untuk menyebut pentingnya sistem pemidanaan struktural, yang mengandung arti pula kebijakan integral dalam sistem pemidanaan.

Secara sederhana bisa digambarkan, selama ini dalam sistem pemidanaan di Indonesia fokus tindak pidana dan pertanggungjawaban pidana adapada individuindividu langsung yang terlibat dalam proses tindak pidana. Padahal sering ada keterlibatan pihak lain selain individu bersangkutan yang juga dapat dimintai pertanggungjawaban sebagai dampak dari terjadinya suatu tindak pidana. Contoh konkret, bila seorang anak melakukan tindak pidana, "pidana"-nya tidak hanya diberikan pada anak tersebut, tetapi pada orang tuanya meskipun pidana yang dijatuhkan misalnya berupa pidana denda. Ini karena menggunakan logika bahwa anak masih merupakan tanggung jawab orang tua, sehingga orang tua juga bertanggung jawab terhadap perbuatan yang dilakukan anaknya. Model ini tampaknya lebih memberikan efek jera baik bagi anak yang melakukan tindak pidana maupun orang tua yang selama ini lalai memberikan pengawasan pada anaknya.

Pemidanaan secara sederhana dapat diartikan dengan penghukuman. Penghukuman yang dimaksud berkaitan dengan penjatuhan pidana dan alasan-alasan pembenar (justification) dijatuhkannya pidana terhadap seseorang yang dengan putusan pengadilan yang telah berkekuatan hukum tetap (incrachtvangewijsde) dinyatakan secara sah dan meyakinkan terbukti melakukan tindak pidana. Tentunya, hak penjatuhan pidana dan alasan pembenar penjatuhan pidana serta pelaksanaannya tersebut berada penuh di tangan negara dalam realitasnya sebagai roh.Sesuai dengan apa yang dikatakan oleh (Barda Nawawi Arief, 2018): bahwa tujuan dari kebijakan pemidanaan yaitu menetapkan suatu pidana tidak terlepas dari tujuan politik kriminal. Dalam arti keseluruhannya yaitu perlindungan masyarakat untuk mencapai kesejahteraan. Oleh karena itu untuk menjawab dan mengetahui tujuan serta fungsi pemidanaan, maka tidak terlepas dari teori-teori tentang pemidanaan yang ada.

Dari penjabaran stelsel pidana di atas, masing masing ketentuan sanksi pidana tersebut semuanya masih berlaku dan masih diterapkan hingga saat ini termasuk ketentuan stelsel pidana yang paling berat sebagaiman yang diatur di Pasal 10 yaitu Pidana mati. Pidana mati merupakan sanksi yang paling berat di KUHP sebab melalui ketentuan pasal tersebut, hakim dapat merampas nyawa terpidana apabila ia terbukti secara sah dan meyakinkan melakukan tindak pidana yang diancam pidana mati. Mengenai pelaksanaan pidana mati di dalam sistem hukum Indonesia, pelaksanaan pidana mati mengami migrasi dasar hukum yang cukup berpengaruh. Dari yang semula pidana mati dilaksanakan dengan cara digantung oleh Algojo sampai mati sebagaimana yang diatur di dalam Pasal 11 KUHP, kini ketentuan hukum tersebut tidak lagi digunakan seiring dengan terbitnya UU Nomor 2 /PNPS/1964 yang mengatur bahwa pelaksanaan pidana mati dilakukan dengan cara ditembak tepat di jantung. 
Dalam praktik penegakan hukum pidana Indonesia, begitu terdakwa dijatuhi vonis hukuman mati oleh majelis hakim, ia menunggu masa eksekusi mati di dalam sel tahanan sampai hari pelaksanaan eksekusi mati dilaksanakan. Menjadi persoalan adalah bahwa peraturan perundang undangan yang mengatur tentang pidana mati di Indonesia tidak mengatur secara pasti kapan tenggat waktu pelaksanaan eksekusi pidana mati sejak terpidana divonis hukuman mati oleh majelis hakim. Ketidakpastian ini menimbulkan masalah sebab ketidakpastian tersebut membawa dampak bagi terlanggarnya hak asasi terpidana dalam hak memperoleh kepastian hukum.

Di dalam KUHP bila sudah diketahui bahwa pentingnya pemidanaan struktural, patut dipikirkan rumusannya yang tepat untuk memenuhi kebutuhan hukum positif. Kita dapat beranjak dari perbandingan pemidanaan struktural yang diberlakukan di negara lain, terkait dasar atau landasan filosofis pengaturan, aturan hukum positif, dan model pertanggungjawaban pidananya. Landasan filosofis bagi KUHP untuk penerapan pemidanaan struktural adalah berpegang pada bahwa pertanggungjawaban pidana terkadang melibatkan pihak lain selain pelaku, tindak pidana, atau adanya kelalaian dalam menjalankan kebijakan sehingga terjadi tindak pidana yang tidak dinginkan (Alin, 2017). Dalam konsep pembaruan KUHP di Indonesia, ide ini dicerminkan dalam "ide keseimbangan/monodualistik".

Selama ini kita hanya berpegang pada adanya kesalahan dalam tindak pidana, atau sering disebut "tiada pidana tanpa kesalahan" (asas culpabilitas), meskipun dalam KUHP lama (WvS) hal ini juga belum diatur. Namun dalam perkembangan saat ini, asas itu tidak cukup. Saat ini hukum pidana lebih menuntut adanya keseimbangan karena melihat tujuan adanya hukum adalah keadilan, kemanfaatan, dan kepastian hukum. Bila selama ini kita hanya melihat hukum sebagai sesuatu untuk mencapai kepastian hukum, hal inilah yang perlu dibenahi. mua aturan perundang-undangan mengenai hukum pidana subtantif, hukum pidana formal dan hukum pelaksanaan pidana dapat dilihat sebagai satu kesatuan sistem pemidanaan. Dengan demikian dapatlah dikatakan bahwa pemidanaan tidak dapat terlepas dari jenis-jenis pidana yang diatur dalam hukum positif suatu negara. Pemidanaan yang dilakukan oleh suatu masyarakat yang teraturterhadap pelaku kejahatan dapat berbentuk menyingkirkan atau melumpuhkan para pelaku tindak pidana, sehingga pelaku tersebut tidak lagi mengganggu di masa yang akan datang.

\section{Metode Penelitian}

Menurut Peter Mahmud Marzuki sebagaimana yang dikutip oleh (Nugraha, 2017) dalam penelitian hukum, terdapat beberapa jenis (metode) pendekatan, yang setidaknya akan menggunakan satu, dalam usaha mengumpulkan dan mendaatkan informasi dari berbagai aspek untuk menjawab sebuah permasalahan hukum (Marzuki, 2014). Jenis penelitian yang digunakan dalam penelitian ini adalah Yuridis Normatif. Menurut (Muchtar, 2015), penelitian Yuridis Normatif adalah metode penelitian hukum yang dilakukan dengan cara meneliti bahan pustaka atau bahan sekunder belaka (Muchtar, 2015). Menurut (Soerjono Soekanto, 2019) sebagaimana yang dikutip oleh (Suteki, 
2018), penelitian merupakan suatu sarana pokok dalam pengembangan pengetahuan maupun teknologi. Hal ini disebabkan, oleh karena penelitian bertujuan untuk mengungkapkan kebenaran secara sistematis, metodologis, dan konsisten. Melalui proses penelitian tersebut diadakan analisis dan konstruksi terhadap data yang telah dikumpulkan dan diolah (Suteki, 2018).

Metode penelitian ditujukan untuk mengtahui serangkaian metode yang digunakan dalam penulisan hukum dan diharapkan dapat diperoleh sebuah penelitian yang sistematis dan juga untuk memperoleh hasil penelitian yang diharapkan dapat menjadi penelitian yang sistematis dan dapat dipertanggungjawabkan secara ilmiah. Penelitian Yuridis Normatif ini, yakni penelitian berdasarkan aturan aturan yang diatur dalam peraturan perundang undangan kemudian mendeskripsikan secara faktual tentang pengaturan tenggat waktu bagi terpidana dalam pelaksanaan eksekusi pidana mati (Anjarsari, 2021). atut diketahui, bahwa tidaklah semua filsuf ataupun pakar hukum pidana sepakat bahwa negaralah yang mempunyai hak untuk melakukan pemidanaan (subjectief strafrech). Hal ini dapat terlihat jelas pada pendapat Hezewinkel-Suringa yang mengingkari sama sekali hak mempidana ini dengan mengutarakan keyakinan mereka bahwa si penjahat tidaklah dilawan dan bahwa musuh tidaklah boleh dibenci.

Konsep KUHP baru yang idenya adalah keseimbangan, maka upaya untuk mencapai tujuan yang lain yakni keadilan dan kemanfaatan juga akan diakomodasi, yang salah satunya sebenarnya bisa dalam bentuk pengaturan pemidanaan struktural. Apalagi bila mengingat salah satu ide dasar sistem pemidanaan dalam konsep KUHP baru adalah ide mendahulukan keadilan dari kepastian hukum. Bila ternyata dalam konsep KUHP baru belum tercermin tentang pemidanaan struktural.

\section{Hasil dan Pembahasan}

\section{Pengaturan Pidana Mati di Indonesia}

Sanksi Pidana diatur di dalam sejumlah undang undang. Meskipun tersebar, namun ketentuan pidana mati merujuk pada stelsel pidana sebagaimana yang diatur di dalam ketentuan Pasal 10 A Ayat 1 KUHP. Pasal 10 A Ayat 1 KUHP mengatur bahwa sanksi pidana terberat adalah pidana mati (Kansil, 2014). Indonesia dengan KUHP yang pada waktu itu bernama Wetboek van Strafrecht voor Nederlandsch Indie dengan pemberlakuan asas konkordansi sebagaimana yang diberlakukan oleh Belanda sebagai negara penjajah saat itu. Berbeda dengan Belanda yang pada saat ini tidak lagi memberlakukan pidana mati karena lembaga pidana mati telah dihapus sejak KUHP Belanda tahun 1881, Indonesia hingga saat ini masih memberlakukan pidana mati sebagai ancaman pidana terberat.

KUHP Indonesia mengatur beberapa pasal yang diancam dengan pidana mati seperti Pasal 104, Pasal 110 Ayat 1, Pasal 110 Ayat 2, Pasal 111 Ayat 2, Pasal 112, Pasal 113, Pasal 123, Pasal 124 Ayat 1, Pasal 124 bis, Pasal 125, pasal 127, Pasal 129, Pasal 140 Ayat 3, Pasal 185, Pasal 340, Pasal 444, Pasal 479 ayat 2. Ketentuan pidana juga diatur di dalam undang undang diluar KUHP diantaranya di dalam Kitab Undang Undang Hukum Pidana Militer di dalam ketentuan Pasal 64 angka 1 
dan 2, Pasal 65 Angka 2 dan 3, Pasal 66, 67, dan Pasal 68. Ketentuan pidana juga diatur di dalam Pasal 81 Ayat 3 UU Nomor 35 Tahun 2009 tentang Narkotika.

Pelaksanaan pidana mati pada awalnya sebagaimana yang diatur oleh Pasal 11 KUHP dilakukan oleh seorang algojo dengan cara menggantung terpidana di atas tiang gantungan sampai mati, namun ketentuan pada pasal tersebut sudah tidak berlaku lagi sejak adanya UU Nomor 2 /PNPS/Tahun 1964 dimana pelaksanaan pidana mati adalah dengan ditembak sampai mati. Di dalam ketentuan undang undang a quo pelaksanaan pidana mati diatur di dalam Pasal 2-16 UU diantaranya adalah:

a. Dalam jangka waktu tiga kali dua puluh empat jam sebelum saat pelaksanaan pidana mati itu dilaksanakan, jaksa tinggi atau jaksa yang bersangkutan harus memberitahukan kepada terpidana mati tentang akan dilaksanakannya pidana mati tersebut. Apabila terpidana berkeinginan untuk mengemukakan sesuatu, maka keterngan atau pesannya itu diterima oleh jaksa tinggi atau oleh jaksa tersebut.

b. Apabila terpidana merupakan seorang wanita yang sedang hamil, maka pelaksanaan dari pidana mati harus ditunda hingga anak yang dikandungnya itu telah lahir.

c. Tempat pelaksanan pidana mati ditentukan oleh Menteri Kehakiman yakni di daerah hukum dari pengadilan tingkat pertama yang telah memutuskan pidana mati yang bersangkutan.

d. Kepala Polisi dari daerah yang bersangkutan bertanggung jawab mengenai pelaksanaan dari pidana mati tersebut setelah mendengar nasihat dari jaksa tinggi atau dari jaksa yang telah melakukan penuntutan pidana mati pada peradilan tingkat pertama.

e. Pelaksanaan pidana mati itu dilakukan oleh suatu regu penembak polisi di bawah pimpinan seorang perwira polisi.

f. Kepala Polisi dari daerah yang bersangkutan atau perwira yang ditunjuk harus menghadiri pelaksanaan dari pidana mati itu sedang pembela dari terpidana atas permintaannya sendiri atau atas permintaan dari terpidana dapat menghadirinya.

g. Pelaksaaan pidana mati itu tidak boleh dilakukan di muka umum.

h. Penguburan jenazah terpidana diserahkan kepada keluarga atau kepada sahabat sahabat terpidana, dan harus dicegah pelaksanaan dari penguburan yang sidat demonstrative, kecuali demi kepentingan umum maka jaksa tinggi atau jaksa yang bersangkutan dapat menentukan lain.

i. Setelah pelaksanaan dari pidana mati itu selesai dikerjakan, jaksa tinggi atau jaska yang bersangkutan harus membuat berita acara mengenai pelaksanaan dari pidana mati tersebut, dimana isi dari berita acara tersebut kemudian dicantumkan di dalam Surat Keputusan dari Pengadilan yang bersangkutan.

\section{Pengaturan Tenggat Waktu Pelaksanaan Pidana Mati di Indonesia}

Apabila kita mencermati dari rangkaian pelaksanaan eksekusi pidana mati sebagaimana yang diatur di dalam UU Nomor 2/PNPS/1964 tentang eksekusi pidana 
mati, dapat diketahui bahwa dalam UU a quo belum mengatur tenggat waktu kapan pelaksanaan pidana mati harus dilakukan. UU Nomor 2/PNPS/1964 hanya mengatur pemberitahuan kepada terpidana bahwa ia akan dieksekusi paling lama dalam waktu 3 x 24 jam. Namun itu baru sebatas pada pemberitahuan menjelang eksekusi mati. UU Nomor 2/PNPS/1964 tidak mengatur secara pasti interval waktu pelaksanaan pidana mati dari sejak penjatuhan vonis hukuman mati oleh hakim sampai pada hari pelaksanaan eksekusi mati dilakukan.

Ketidak pastian pengaturan tenggat waktu ini menurut argumentasi penulis menimbulkan ketidakpastian hukum dan akan berdampak pada keadaan psikologis terpidana. Hal demikian sebab ia sudah tau bahwa ia akan mati ditembak pada akhirnya, namun tidak tahu kapan ia akan ditembak. Dalam praktik pelaksanan pidana mati di Indonesia, rentang waktu antara vonis majelis hakim hingga hari pelaksanaan hukuman mati dilakukan kepada terpidana pada realitanya memakan waktu yang sangat lama, bertahun tahun bahkan lebih dari satu decade, terpidana mati belum juga dieksekusi.Dalam hal ini, penulis paparkan beberapa contoh kasus konkret tentang pelaksanaa pidana mati yang berlarut larut :

Pertama, kasus pembunuhan berantai yang menggegerkan publik Tanah Air pada 2008. Very Idam Henyansyah alias Ryan, pria dari Jombang, Jawa Timur membunuh 11 orang. Dari informasi yang dihimpun Sejarah Hari Ini, terkuaknya pembunuhan yang dilakukan Ryan dimulai dari ditemukannya tujuh potongan tubuh manusia dalam dua buah tas di belakang Kebun Binatang Ragunan, Jakarta Selatan, pada Sabtu pagi 12 Juli 2008. Polisi kemudian membawa jenazah korban mutilasi itu ke Rumah Sakit Cipto Mangunkusumo (RSCM), Jakarta Pusat. Identitas jenazah terungkap. Dia adalah Heri Santoso (40), seorang manager penjualan sebuah perusahaan swasta di Jakarta yang menghilang selama dua hari. Pada Selasa 15 Juli 2008, polisi menangkap Very Idam Henyansyah alias Ryan. Dia ditangkap setelah menggunakan uang sebesar Rp 3.040.000, kartu kredit dan ATM milik Heri untuk berfoya-foya dengan kekasih sesama jenisnya, Noval Andrias. Saat itu, dia ditangkap di kosnya di Pesona Kayangan, Depok. Polisi juga menangkap kekasih Ryan, Noval. Penyidik kemudian menggiring Ryan dan Noval ke Polda Metro Jaya pada hari itu juga untuk diperiksa.

Pada pemeriksaan tersebut, penyidik menghubungkan kasus mutilasi ini dengan hilangnya Aril Somba Sitanggang alias Aril. Ryan pernah dilaporkan keluarganya pada Mei 2008 karena menghilang. Pada saat itu, polisi melepaskannya karena tidak cukup bukti. Ryan pun mengaku telah memakamkan jenazah Aril di dekat rumah orangtuanya di Desa Jatiwates Kecamatan Tembelang, Kabupaten Jombang, Jawa Timur. Senin, 21 Juli 2008, polisi menggiring Ryan untuk menunjukkan lokasi penguburan Aril. Saat itu, polisi menemukan empat mayat dalam dua lubang. Salah satunya diyakini sebagai jasad Aril. Satu lubang berisi tiga jenazah. Satu korban berjenis kelamin wanita. Jenazah perempuan itu ditemukan dalam satu liang lahat bersama dua jenazah laki-laki lainnya di belakang pintu dapur rumah keluarga Ryan. Lubang yang lain berisi satu jasad berjenis kelamin laki-laki 
ditemukan petugas dalam sebuah liang di bawah pohon bambu yang berjarak sekitar lima meter dari liang pertama. Ryan mengaku melakukan pembunuhan itu sendirian di belakang rumahnya di Jalan Melati, Desa Jatiwates. Rentang pembunuhan dilakukan dari 2007, hingga akhirnya terungkap ada 11 korban jiwa. Pada 6 April 2009, majelis hakim Pengadilan Negeri Depok menjatuhi vonis hukuman mati terhadap Ryan, dan hingga saat ini Ryan belum dieksekusi.

Kedua, kasus Bom Bali 1 dengan terpidana mati Amrozi dan Imam Samudera. Pengeboman di sejumlah tempat di Bali--atau dikenal dengan sebutan peristiwa Bom Bali I--berawal ketika Umar Patek memutuskan tinggal di Sukoharjo, yaitu di rumah kontrakan Dulmatin. Hal ini dilakukan Umar Patek agar memudahkan komunikasi dengan Dulmatin, terkait rencana perlawanan mereka terhadap tentara Amerika Serikat dan sekutunya. Rencana ini disepakati saat mereka mengikuti pelatihan di Afganistan pada bulan September 2002. Pada saat Umar berada di rumah Dulmatin itulah, Umar ditemui oleh Imam Samudra dan mengajaknya untuk membunuh orang-orang asing yang berada di Bali, menggunakan bom. Selanjutnya, Dulmatin menemui Umar untuk memintanya segera ke Denpasar, Bali dan memberikan informasi bahwa Imam Samudra sudah berada di Bali. Umar pun berangkat melalui terminal Tirtonadi Solo diantar Dulmatin dengan menggunakan sepeda motor. Sesampainya di terminal Ubung Denpasar Bali, Umar dijemput oleh Imam Samudra dan Idris dengan menggunakan mobil Feroza. Lalu mereka menuju rumah kontrakan yang telah disediakan Imam Samudra yang beralamat di Jalan Pulau Menjangan, Denpasar.

Setelah berada di kontrakan tersebut, Umar bertemu dengan Sarjiyo dan Sawad yang tengah meracik dan mencampur bahan peledak jenis potasium klorat, sulfur dan bubuk alumunium. Umar dan kedua orang tersebut kenal sejak samasama sekolah di Akademi Militer milik Mujahidin Afganistan di Saddah, Pakistan pada tahun 1991 sampai 1993. Imam Samudra lalu meminta Umar untuk membuat bahan peledak bersama Sarjono alias Sawad. Proses pembuatan bubuk hitam itu dilakukan selama tiga minggu. Setelah itu, Ali Imron datang ke rumah itu bersama dengan Dr. Azhari, Dulmatin, Muklas, Amrozi dan Abdul Ghoni. Mereka datang menggunakan mobil L 300 berwarna putih dengan membawa empat set filing cabinet sebagai wadah bom. Setelah bahan peledak selesai dibuat oleh Umar, kemudian bersama Dr. Azhari dan Sawad, Umar memasukkan bubuk hitam ke dalam empat filing cabinet tersebut. Sementara itu, Dulmatin membuat rangkaian elektronik bom. Kemudian, Umar dan Dr. Azhari merangkai detonating cord dari satu filing cabinet ke filing cabinet lain. Selanjutnya filling cabinet tersebut diletakkan di mobil L 300. Setelah itu, Dulmatin melanjutkan pemasangan rangkaian elektronik bom di mobil L 300 antara filing cabinet satu dan yang lain. Umar dan Dr. Azhari juga membuat bom rompi dengan menggunakan sepuluh potong pipa paralon yang diisi dengan bahan peledak. Selain itu juga membuat bom kotak. Pada Kamis, tanggal 10 Oktober 2002 bom mobil Mitsubishi L 300, bom rompi dan bom kotak selesai dibuat dan siap diledakkan. 
Pada hari yang sama, sekitar pukul 16.00 WITA, Dulmatin dan Dr. Azhari mengajari Ali Imron untuk menyalakan switch bom yang terpasang di mobil, rompi dam kotak. Cara menyalakan switch inilah, yang diajarkan Ali Imron kepada Jimi alias Arnasal Iqbal alias Isa yang telah dipersiapkan sebagai eksekutor bom bunuh diri. Sementara pada malam harinya, Ali Imron dan Idris menguji kesiapan Jimi dalam hal mengendarai mobil. Setelah itu, Dulmatin dan Dr. Azhari meninggalkan Denpasar. Sementara Umar dan Abdul Ghoni tetap di Denpasar.

Kemudian, pada Jumat 11 Oktober 2002, sekitar pukul 08.00 WITA, Umar meninggalkan rumah itu menuju Surabaya dengan menggunakan bus. Pada Sabtu pagi, 12 Oktober 2002 Ali Imron memasang tiga switch bom di sebelah kiri jok sepeda motor Yamaha FIZR warna merah. Masing-masing satu switch untuk mematikan mesin motor, satu switch untuk mematikan lampu rem belakang dan satu switch untuk mematikan lampu belakang. Ali Imron kemudian menentukan lokasi sasaran peledakan bom, yaitu di Konsulat Amerika Serikat di Renon, Sari Club dan Paddy's Pub di Legian, Kuta, Bali. "Karena di tempat tersebut banyak berkumpul orang asing," kata dia.

Pada 12 Oktober 2002, Ali Imron pada pukul 20.45 WITA, dengan menggunakan sepeda motor Yamaha dengan membawa satu bom kotak yang beratnya sekitar 6 kilogram dengan sistem remote handphone. Bom tersebut, kemudian diletakkan di trotoar di samping kanan kantor Konsulat Amerika Serikat. Ali Imron lalu pergi ke Sari Club dan Paddy's Pub untuk melihat situasi serta arus lalu lintas. Setelah itu, Ali Imron kembali ke rumah kontrakan tersebut. Kemudian sekitar pukul 22.30 WITA, Ali Imron bersama dengan Jimi menuju Legian dengan menggunakan mobil L 300. Sementara Idris mengikuti dengan menggunakan motor Yamaha. Setibanya di lokasi, Ali Imron menyuruh Iqbal untuk mengenakan bom rompi dan menyuruh jimi untuk menggabungkan kabel-kabel dari detonator ke kotak switch bom mobil L 300. Selanjutnya, ketika mendekati pertigaan Jalan Legian, Iqbal dan Jimi telah siap untuk melakukan aksi bom. Pada saat itu, Ali Imron turun dari mobil L 300 yang telah diparkir sekitar 50 meter dari pertigaan. Selanjutnya, Jimi mengambil alih kemudi untuk melaksanakan tugasnya melakukan bom bunuh diri di depan Sari Club. Sementara Iqbal melaksanakan tugasnya untuk meledakkan bom rompi di Paddy's Pub.

Di lokasi tersebut, Idris menjemput Ali Imron dengan sepeda motor Yamaha menuju jalan Imam Bonjol. Dari tempat inilah, Ali Imron menggunakan handphone sebagai remote control dan menekan nomor handphone yang terpasang pada bom yang telah diletakkan di depan Konsulat Amerika. Sekitar satu menit kemudian, Ali Imron telah mendengar suara ledakan dahsyat dari arah Kuta yang diyakini bahwa ledakan itu berasal dari bom mobil L 300 yang telah diledakkan oleh Jimi. Satu minggu setelah peledakan bom itu, Umar hadir dalam pertemuan dengan Dulmatin di Surakarta. Pertemuan tersebut dipimpin Muklas, dan dihadiri oleh Amrozi, Imam Samudra, Dulmatin, Ali Imron, Sawad, Abdul Ghoni, dan Idris. Pertemuan tersebut membahas keberhasilan pengeboman di Bali. Sementara pengeboman di tiga tempat 
tersebut mengakibatkan 192 orang meninggal. Sebanyak 187 orang telah teridentifikasi, 5 jenazah belum teridentifikasi dan 197 potongan tubuh belum teridentifikasi. Ledakan juga mengakibatkan 422 unit fasilitas publik rusak, di antaranya jaringan telepon, listrik dan saluran PDAM. Pada Tahun 2003, Amrozi dan Imam Samudera divonis hukuman mati dan baru dieksekusi pada tahun 2008 setelah lima tahun vonis majelis hakim.

Dari paparan di atas, dapat disimpulkan bahwa sejatinya hukum pelaksanaan pidana Indonesia in casu hukum pidana mati tidak mengatur secara pasti tentang waktu pelaksanaan eksekusi mati terhitung dari vonis yang dijatuhkan oleh majelis hakim hingga hari pelaksanaan. Mengenai kapan terpidana akan dieksekusi sepenuhnya bergantung dari kebijakan jaksa selaku pelaksana putusan hakim. Hal itu tidak seharusnya tidak dikonstruksikan demikian karena dalam diskursus ilmu hukum pada umumnya, seharusnya hukum mengatur memberikan kepastian hukum tidak hanya dari segi hukum materiil, namun juga formil hingga pelaksanaannya. Hal itu juga diperkuat bahwa meskipun pada dasarnya hukum pidana adalah hukum yang memberikan nestapa dan melanggar hak asasi manusia, namun bukan berarti bahwa hukum pidana lepas dari tiga dasar nilai hukum yakni keadilan, kemanfaatan, dan juga kepastian.

\section{Kesimpulan}

Pidana mati merupakan sanksi yang paling berat di KUHP sebab melalui ketentuan pasal tersebut, hakim dapat merampas nyawa terpidana apabila ia terbukti secara sah dan meyakinkan melakukan tindak pidana yang diancam pidana mati. Mengenai pelaksanaan pidana mati di dalam sistem hukum Indonesia, pelaksanaan pidana mati mengami migrasi dasar hukum yang cukup berpengaruh. Dari yang semula pidana mati dilaksanakan dengan cara digantung oleh Algojo sampai mati sebagaimana yang diatur di dalam Pasal 11 KUHP, kini ketentuan hukum tersebut tidak lagi digunakan seiring dengan terbitnya UU Nomor 2 /PNPS/1964 yang mengatur bahwa pelaksanaan pidana mati dilakukan dengan cara ditembak tepat di jantung.

UU Nomor 2/PNPS/1964 tentang eksekusi pidana mati, dapat diketahui bahwa dalam UU a quo belum mengatur tenggat waktu kapan pelaksanaan pidana mati harus dilakukan. UU Nomor 2/PNPS/1964 hanya mengatur pemberitahuan kepada terpidana bahwa ia akan dieksekusi paling lama dalam waktu 3 x 24 jam. Namun itu baru sebatas pada pemberitahuan menjelang eksekusi mati. UU Nomor 2/PNPS/1964 tidak mengatur secara pasti interval waktu pelaksanaan pidana mati dari sejak penjatuhan vonis hukuman mati oleh hakim sampai pada hari pelaksanaan eksekusi mati dilakukan. Ketidak pastian pengaturan tenggat waktu ini menimbulkan ketidakpastian hukum dan akan berdampak pada keadaan psikologis terpidana. Hal demikian sebab ia sudah tau bahwa ia akan mati ditembak pada akhirnya, namun tidak tahu kapan ia akan ditembak. Dalam praktik pelaksanan pidana mati di Indonesia, rentang waktu antara vonis majelis hakim hingga hari pelaksanaan hukuman mati dilakukan kepada terpidana pada realitanya memakan waktu yang sangat lama, bertahun tahun bahkan lebih dari satu 
decade, terpidana mati belum juga dieksekusi. hukum pelaksanaan pidana Indonesia in casu hukum pidana mati tidak mengatur secara pasti tentang waktu pelaksanaan eksekusi mati terhitung dari vonis yang dijatuhkan oleh majelis hakim hingga hari pelaksanaan. Mengenai kapan terpidana akan dieksekusi sepenuhnya bergantung dari kebijakan jaksa selaku pelaksana putusan hakim. Hal itu tidak seharusnya tidak dikonstruksikan demikian karena dalam diskursus ilmu hukum pada umumnya, seharusnya hukum mengatur memberikan kepastian hukum tidak hanya dari segi hukum materiil, namun juga formil hingga pelaksanaannya. 


\section{BIBLIOGRAFI}

Alin, Failin. (2017). Sistem Pidana dan Pemidanaan di dalam Pembaharuan Hukum Pidana Indonesia. JCH (Jurnal Cendekia Hukum), 3(1), 14-31. Google Scholar

Anjarsari, Wulan Puji. (2021). Pengaturan Tenggat Waktu Pelaksanaan Pidana Mati dalam Hukum Pidana Indonesia. Jurnal Indonesia Sosial Teknologi, 2(3), 485494. Google Scholar

Barda Nawawi Arief, S. H. (2016). Bunga rampai kebijakan hukum pidana. Prenada Media. Google Scholar

Barda Nawawi Arief, S. H. (2018). Masalah penegakan hukum dan kebijakan hukum pidana dalam penanggulangan kejahatan. Prenada Media. Google Scholar

Hiariej, Eddy O. S., \& Uno, Sandiaga S. (2020). Korupsi mengorupsi Indonesia. Google Scholar

Kansil, Fernando I. (2014). Sanksi Pidana dalam Sistem Pemidanaan Menurut KUHP dan di Luar KUHP. Lex Crimen, 3(3). Google Scholar

Lamintang, PA. .. (2017). Hukum Penitensier Indonesia (Cet 3 Edis). Jakarta: Sinar Grafika.

Marbun, Rocky. (2014). Grand Design Poli k Hukum Pidana dan Sistem Hukum Pidana Indonesia Berdasarkan Pancasila dan Undang-Undang Dasar Negara Republik Indonesia 1945 A . Pendahuluan Sejak era tahun tujuh puluhan, masyarakat hukum Indonesia sangat mengenal ungkapan " hukum seb. Padjadjaran Jurnal Ilmu Hukum, 1(3), 558-577. Retrieved from http://jurnal.unpad.ac.id/pjih/article/view/7095 Google Scholar

Marzuki, Peter Mahmud. (2014). Penelitian Hukum. Jakarta: Kencana Prenada Media Group. Google Scholar

Muchtar, Henni. (2015). Analisis Yuridis Normatif Sinkronisasi Peraturan Daerah dengan Hak Asasi Manusia. Humanus, 14(1), 80-91. Google Scholar

Nugraha, Dwi Putra et al. (2017). Mengamandemen Ketentuan yang Tidak Dapat Diamandemen dalam Konstitusi Republik Indonesia. Cet 1. Yogyakarta: Thafa Media.

Soerjono Soekanto. (2019). Pengantar Penelitian Hukum. Jakarta: UI Press. Google Scholar

Sudarto. (2013). Hukum Pidana 1 . Cet 4. Semarang: Badan Penerbit Universitas Diponegoro.

Suteki, Galang Taufani. (2018). Metodologi Penelitian Hukum. Raja Grafindo Persada. 
Pengaturan Tenggat Waktu Pelaksanaan Pidana Mati dalam Hukum Pidana Indonesia

Google Scholar

Copyright holder:

Dimas Pranowo (2022)

First publication right:

Syntax Literate: Jurnal Ilmiah Indonesia

This article is licensed under:

(c) (i) (2) 